\title{
PEMBANGUNAN EKONOMI BERBASIS AGRIBISNIS SEBAGAI WUJUD DARI PEMBANGUNAN EKONOMI YANG BERKELANJUTAN
}

\author{
Muchammad Nurif* \\ Sukrianti Mukhtar
}

\begin{abstract}
Abstrak
Dalam menghadapi era globalsisasi, Indonesia sebagai negara berkembang membutuhkan suatu strategi besar dalam pembangunan ekonomi. Dalam kaitannya dengan Indonesia yang merupakan negara agraris yang besar dan memiliki keanekaragaman hayati, seharusnya Indonesia memiliki sektor andalan yang dapat dijadikan sebagai tumpuan harapan pembangunan ekonomi dalam rangka mewujudkan tujuan nasional. Sangat disayangkan jika pembangunan ekonomi di Indonesia tanpa mengindahkan kelestarian keanekaragaman hayati dan tidak memperhitungkan kondisi yang akan terjadi di masa mendatang. Oleh karena itu, dibutuhkan suatu strategi pembangunan ekonomi yang berkelanjutan. Pembangunan ekonomi yang berbasis agribisnis merupakan salah satu solusi untuk meningkatkan daya saing ekonomi bagi Indonesia.
\end{abstract}

Kata kunci : pembangunan ekonomi, agribisnis, berkelanjutan.

Sektor andalan perekonomian ialah sektor yang memiliki ketangguhan dan kemampuan tinggi sehingga dijadikan sebagai tumpuan harapan pembangunan ekonomi dalam rangka mewujudkan tujuan nasional. Sektor andalan merupakan tulang punggung an penggerak perekonomian, sehingga dapat juga disebut sebagai sektor kunci atau sektor pemimpin perekonomian nasional. Dengan demikian, sektor andalan merupakan refleksi dari suatu strutkur perekonomian, sehingga dapat pula dipandang sebagai salah satu aspek penciri atau kharakteristik dari suatu perekonomian.

Dari sekian banyak pemikiran yang telah dilontarkan, secara umum terdapat tiga jalur pilihan yang memiliki potensi untuk memacu pertumbuhan ekonomi Indonesia. Tanpa hendak memperdebatkan secara rinci keunggulan masing-masing, apalagi "falsafah dasarnya", jalur pilihan tersebut adalah sebagai berikut.

Jalur Pertama mengandalkan pada industri yang berbasis luas (broad-based industry) yang (tentunya) mengembangkan kegiatan-kegiatan yang memiliki keunggulan komparatif dan kompetitif. Dengan kebijaksanaan dan strategi ini, terbuka kesempatan untuk mengembangkan kegiatan-kegiatan yang bersifat foot-

\footnotetext{
* Dosen pada UPM Soshum ITS

jsh Jurnal Sosial Humaniorah, Vol 3 No.2, November 2010 
loose industry; yakni industri yang tidak lagi diminati negara penemunya atau negara pengguna lain karena nilai tambah yang diciptakan tidak mampu membayar ongkos produksi yang kompetitif (terutama upah) di negara tersebut. Namun dalam prakteknya, negara penemu teknologinya masih tetap berusaha mendapatkan economic rent dari temuan teknologi tersebut. Paling-paling negara baru pengguna hanya menguasai teknologi perakitannya saja.

Jalur Kedua, mungkin karena kelemahan jalur pertama yang dianggap cukup mendasar, yakni ketergantungan terhadap teknologi yang masih dikuasai oleh negara penemunya, maka muncul pemikiran baru. Pemikiran baru tersebut ialah mencoba mengandalkan industri atau kegiatan-kegiatan strategis yang memanfaatkan teknologi canggih dan rumit (hi-tech industry), serta bernilai tambah tinggi. Hal ini didasarkan atas perkiraan kuat bahwa apabila kita mampu menguasai teknologi canggih dan rumit, maka akan lebih mudah menguasai teknologi pada jenjang lebih bawah (intermediate and lo-tech industry).

Dengan pemikiran seperti ini, upaya dan investasi untuk membangun industri ("strategis") seperti Pusat Pembangkit Listrik Tenaga Nuklir (PLTN), Bio technology, pemanfaatan satelit komunikasi, dan lain-lain menjadi dapat dibenarkan. Sebelum itu, pemanfaatan teknologi canggih, rumit, dan bernilai-tambah tinggi baru terbatas dalam bidang eksplorasi serta penambangan minyak dan gas bumi. Hal yang menjadi pertanyaan ialah apakah "jalan pintas" ini benar-benar menyingkat waktu untuk mencapai tingkat pertumbuhan yang tinggi yang sangat didambakan oleh perekonomian kita.

Jalur Ketiga, Dengan dua jalur terdahulu, belum ada jaminan bahwa industrialisasi akan didukung oleh pertanian (dan pedesaan) yang tangguh. Industrialisasi tanpa membenahi sektor pertanian (dan pedesaan) terlebih dahulu, atau transformasi ekonomi yang tidak seimbang, pada gilirannya akan menyebabkan sektor pertanian dan pedesaan itu menjadi beban pembangunan. Pertumbuhan ekonomi bisa tersendat atau, kalaupun pertumbuhan bisa di pacu lebih tinggi, kesenjangan akan semakin melebar serta menimbulkan dampak negatif lain yang cukup serius. 
Oleh sebab itu, setidaknya pada tahap-tahap awal, industrialisasi perlu pula mengandalkan industri atau kegiatan-kegiatan yang memanfaatkan atau menciptakan nilai tambah baru bagi produk-produk pertanian primer, serta industri atau kegiatan lain yang memproduksi bahan-bahan dan alat-alat untuk meningkatkan produktivitas pertanian (agro-industry). Jalur ini juga mempunyai berbagai keunggulan. Apabila berbagai syarat tertentu bisa dipenuhi, maka pendekatan ini benar-benar merakyat dan berkeadilan, tidak anti pertumbuhan dan bersahabat dengan lingkungan serta berkelanjutan.

Fokus pembahasan adalah jalur ketiga, pembangunan agribisnis tanpa memperbandingkan dengan dua lajur lainnya. Secara umum, syarat keharusan agar suatu sektor layak dijadikan sebagai andalan perekonomian nasional ialah memiliki kontribusi yang dominan, baik secara langsung maupun secara tidak langsung, dalam pencapaian tujuan pembangunan perekonomian nasional. Sektor agribisnis jelas memiliki peranan yang sangat dominan, khususnya dalam hal pemantapan ketahanan pangan, pengentasan kemiskinan, penciptaan lapangan kerja, dan pemerataan pendapatan. Kesemuanya ini merupakan tujuan pembangunan ekonomi yang sangat penting, dan bahkan lebih penting daripada peranan dalam kontribusi dan pertumbuhan PDB, dimana saat ini kontribusi sektor agribisnis dalam PDB tidak lagi dominan dan cenderung mengalami penurunan.

Secara rinci ada lima syarat suatu sektor dapat dikatakan sebagai sektor andalan perekonomian nasional, yaitu tangguh, progresif, ukurannya cukup besar, artikulatif dan responsif. Kelima syarat khusus tersebut harus dipenuhi agar suatu sektor dapat menjadi sektor andalan perekonomian nasional. Pembangunan agribisnis diyakini dapat memenuhi persyaratan tersebut secara simultan, sehingga diharapkan mampu menjamin keberlanjutan pembangunan ekonomi nasional. Pembangunan agribisnis sebagai sektor andalan diharapkan mampu mencapai pertumbuhan ekonomi, pemerataan, dan penanganan lingkungan secara inklusif dan integratif.

Sudah saatnya pembangunan ekonomi daerah yang menyangkut sebagian besar kepentingan ekonomi rakyat banyak tidak berhenti pada retorika saja, melainkan harus sesegera mungkin diwujudkan dalam aksi nyata dan dukungan 
kebijaksanaan makro ekonomi. Hal ini antara lain diwujudkan melalui penerapan konsep pengembangan agribisnis dalam pembangunan ekonomi daerah atau pengembangan ekonomi lokal.

\section{Agribisnis}

Agribisnis merupakan suatu sistem yang terdiri atas subsistem hulu, usahatani, hilir, dan penunjang. Menurut Saragih (1998, dalam Pasaribu 1999), batasan agribisnis adalah sistem yang utuh dan saling terkait di antara seluruh kegiatan ekonomi (yaitu subsistem agribisnis hulu, subsistem agribisnis budidaya, subsistem agribisnis hilir, susbistem jasa penunjang agribisnis) yang terkait langsung dengan pertanian.

Agribisnis diartikan sebagai sebuah sistem yang terdiri dari unsur-unsur kegiatan : (1) pra-panen, (2) panen, (3) pasca-panen dan (4) pemasaran. Sebagai sebuah sistem,

kegiatan agribisnis tidak dapat dipisahkan satu sama lainnya, saling menyatu dan saling terkait. Terputusnya salah satu bagian akan menyebabkan timpangnya sistem tersebut. Sedangkan kegiatan agribisnis melingkupi sektor pertanian, termasuk perikanan dan kehutanan, serta bagian dari sektor industri. Sektor pertanian dan perpaduan antara kedua sektor inilah yang akan menciptakan pertumbuhan ekonomi yang baik secara nasional (Gunawan Sumodininggat, 2000).

Perkembangan agribisnis di Indonesia sebagian besar telah mencakup subsistem hulu, subsistem usahatani, dan subsistem penunjang, sedangkan subsistem hilir masih belum berkembang secara maksimal. Industri pupuk dan alat-alat pertanian telah berkembang dengan baik sejak Pelita I hingga saat ini. Telah banyak diperkenalkan bibit atau varietas unggul dalam berbagai komoditi untuk peningkatan produksi hasil pertanian. Demikian juga telah diperkenalkan teknik-teknik bertani, beternak, berkebun, dan bertambak yang lebih baik untuk meningkatkan produktivitas pertanian.

Subsistem penunjang yang bersifat fisik dan fiskal telah lama diperkenalkan kepada para petani. Jaringan irigasi telah banyak dibangun yang mampu mengairi jutaan hektar sawah dan lahan pertanian lainnya, untuk meningkatkan produksi 
pertanian. Demikian juga fasilitas kredit pertanian telah lama diterapkan untuk meningkatkan produksi dan pemasaran berbagai komoditi pertanian.

Meskipun sudah banyak yang telah dilakukan pemerintah dalam upaya mengembangkan agribisnis, tetapi masih terdapat berbagai kendala, terutama dalam menjaga kualitas produk yang memenuhi standar pasar internasional serta kontinuitas produksi sesuai dengan permintaan pasar maupun untuk mampu mendukung suatu industri hilir dari produksi pertanian. Salah satu alternatif untuk menjaga kontinuitas dari kualitas produk adalah dengan mengembangkan kegiatan agribisnis disesuaikan dengan potensi sumber daya alam.

Potensi sumber daya alam tersebut tersebar tidak merata untuk setiap pulau/wilayah/daerah. Oleh sebab itu pengembangannya perlu dikaitkan dengan pengembangan wilayah nasional dan lokal, yang berpedoman kepada Rencana Tata Ruang Wilayah Nasional (RTRWN) dan Rencana Tata Ruang Wilayah Propinsi (RTRWP) yang telah mengidentifikasikan kawasan andalan dan kawasan prioritas pengembangan serta jenis pengembangannya.

Pengembangan agropolitan sangat diperlukan dalam mendukung agribisnis, yang dimasa mendatang berperan sangat strategis dalam pembangunan ekonomi nasional. Agropolitan perlu diposisikan secara sinergis dalam sistem pengembangan wilayah. Implementasi konsep agropolitan dalam pengembangan wilayah dilakukan melalui penerapan sistem pemukiman kota dan pedesaan serta Rencana Tata Ruang Wilayah Propinsi (RTRWP) dan Rencana Tata Ruang Wilayah Kabupaten/Kota (RTRWK) yang terkait dengan kawasan budidaya dan sistem transportasi.

\section{Peranan Dalam Pembangunan Ekonomi Daerah}

Tujuan pokok dari pelaksanaan otonomi daerah sebagaimana maksud dari UU No. 22 tahun 1999 dan PP No. 25 tahun 2000 adalah mempercepat perkembangan ekonomi daerah. Cara yang paling efektif dan efisien untuk membangun ekonomi daerah adalah melalui pendayagunaan berbagai sumberdaya ekonomi yang tersedia di setiap daerah.

Pada saat ini sumberdaya ekonomi yang dimiliki di setiap daerah dan siap didayagunakan untuk pembangunan ekonomi daerah adalah sumberdaya agribisnis seperti sumberdaya alam (lahan, air, keragaman hayati, agro-klimat), sumberdaya 
manusia di bidang agribisnis, teknologi di bidang agribisnis dan lain-lain. Oleh karena itu, untuk membangun ekonomi daerah pilihan yang paling rasional adalah melalui percepatan pembangunan agribisnis. Dengan kata lain, pembangunan agribisnis dijadikan pilar pembangunan ekonomi wilayah.

Pembangunan agribisnis sebagai pembangunan ekonomi di daerah makin relevan pula, mengingat saat ini agribisnis merupakan penyumbang terbesar dalam struktur ekonomi hampir setiap daerah. Sektor agribisnis adalah penyumbang terbesar dalam PDRB dan ekspor daerah. Demikian juga dalam penyerapan tenaga kerja, kesempatan berusaha di setiap daerah, sebagian besar disumbang oleh sektor agribisnis. Karena itu, melalui percepatan modernisasi agribisnis di setiap daerah akan secara langsung memodernisasi perekonomian daerah dan dapat memecahkan sebagian besar persoalan ekonomi di daerah.

\section{Peranan Dalam Ketahanan Pangan Nasional}

Sejarah perjalanan bangsa Indonesia menunjukkan bahwa ketahanan pangan (food security), sangat erat kaitannya dengan ketahanan sosial (socio-security), stabilitas ekonomi, stabilitas politik dan keamanan atau ketahanan nasional (national security) secara keseluruhan. Kelemahan dalam mewujudkan ketahanan pangan akan dengan mudah menggoyahkan ketahanan sosial, ekonomi, politik dan keamanan nasional. Selain itu, ketahanan pangan dalam arti keterjangkauan pangan juga sangat berkaitan erat dengan upaya peningkatan mutu sumberdaya manusia Indonesia. Tanpa dukungan pangan yang bermutu dan cukup, tidak mungkin dihasilkan sumberdaya manusia yang bermutu. Karena itu membangun sistem ketahanan pangan yang kokoh merupakan syarat mutlak bagi pembangunan nasional.

Dalam membangun ketahanan pangan penyediaan pangan dapat diperoleh melalui impor. Namun untuk kondisi Indonesia dimana jumlah penduduknya yang cukup besar dan keragaman sosial budaya yang ada, menggantungkan penyediaan bahan pangan dari pasar internasional akan beresiko tinggi. Selain memerlukan devisa yang cukup besar, juga berhadapan dengan pasar bahan pangan utama dunia yang tipis (thin market), dimana bahan pangan yang diperdagangkan di pasar 
internasional hanya sedikit sekali (sekitar 10-20\% dari total produksi dunia). Karena itu, tidak ada pilihan lain bagi Indonesia kecuali membangun sistem ketahanan pangan yang berakar kokoh pada keragaman sumberdaya bahan pangan, kelembagaan dan budaya lokal.

Produksi pangan domestik telah menunjang sebagian besar penyediaan berbagai pangan nasional. Beberapa komoditas pangan pokok seperti beras dan jagung telah mencukupi kebutuhan masyarakat, sedangkan gula pasir dan kedele masih mengalami defisit. Untuk komoditi ubikayu bahkan mengalami surplus yang cukup tinggi. Keseimbangan antara produksi dengan kebutuhan pangan tersebut bisa dipergunakan untuk mengukur derajat swasembada pangan. Sebagai ilustrasi rasio produksi dan kebutuhan beras, jagung, kedelai, dan ubikayu secara nasional tahun 1999 adalah 0,99; 0,98; 0,58, dan 1,23.

Pembangunan agribisnis sangat besar peranannya dalam menunjang terwujudnya sistem ketahanan pangan yang kokoh. Dengan membangun agribisnis yang berbasis pada keragaman sumberdaya hayati di setiap daerah, serta meningkatkan kesadaran masyarakat terhadap pola konsumsi dan keseimbangan gizi yang mempertimbangkan budaya dan kelembagaan lokal, secara built-in juga terbangun ketahanan pangan yang kokoh.

\section{Masalah Pembangunan Sistem Dan Usaha Agribisnis}

Pembangunan agribisnis di masa lalu, memiliki kelemahan mendasar yang merupakan akar sebagian besar kelemahan agribisnis selama ini. Kelemahan yang dimaksud adalah sebagai berikut.

1. Pembangunan agribisnis dimasa lalu lebih terfokus pada usaha tani (on-farm agribusiness) dengan sasaran utama peningkatan produksi dan kurang memperhatikan industri hulu agribisnis dan industri hilir agribisnis.

2. Pendekatan pembangunan agribisnis di masa lalu sangat sentralistik dan topdown sehingga proses perencanaan pembangunan agribisnisnya dilakukan secara terpusat dan kurang melibatkan partispasi masyarakat. Hal ini dapat menyebabkan :

- Kreativitas rakyat khususnya petani kurang berkembang dan cenderung menumbuhkan sikap ketergantungan pada bantuan pemerintah. 
- Kreativitas dan kearifan lembaga-lembaga lokal (local wisdom) tidak berkembang dan bahkan banyak yang telah hilang.

- Program pembangunan agribisnis menjadi sangat tidak efisien dan efektif karena dengan pendekatan yang demikian memerlukan organisasi dan biaya birokrasi pemerintah yang relatif besar.

- Program pembangunan agribisnis yang dirancang dan diterapkan secara nasional banyak yang tidak sesuai dengan kondisi lokal di setiap daerah.

3. Pembangunan agribisnis di masa lalu kurang didukung oleh kebijaksanaan makro ekonomi yang kondusif. Kebijaksanaan moneter (seperti suku bunga dan kredit) serta fiskal (seperti alokasi anggaran untuk sektor agribisnis) dimasa lalu kurang mendukung sektor agribisnis. Kebijaksanaan perdagangan (trade policy) yang merupakan kombinasi tarif impor, atau pajak ekspor dengan nilai tukar rupiah yang over valued cenderung merugikan agribisnis domestik dan menguntungkan sektor non-agribisnis dan impor.

\section{Visi, Misi, dan Tujuan Pembangunan Sistem dan Usaha Agribisnis}

Kekuatan dan kelemahan pembangunan di masa lalu, perubahan-perubahan lingkungan global, serta menyadari tantangan ke depan, visi pembangunan sistem dan usaha agribisnis yang akan dipromosikan secara nasional adalah:

Terwujudnya perekonomian nasional yang sehat melalui pembangunan agribisnis yang berdaya saing, berkerakyatan, berkelanjutan, dan desentralistis.

\section{Arah Pengembangan Sistem dan Usaha Agribisnis}

Sistem dan usaha agribisnis yang dibangun ke depan adalah suatu sistem dan usaha yang tangguh yang memiliki empat karakteristik yaitu (1) berdaya saing, (2) berkerakyatan, (3) berkelanjutan, dan (4) desentralistis.

\section{Membangun Sistem dan Usaha Agribisnis yang Berdaya Saing}

Daya saing dicirikan oleh tingkat efisiensi, mutu, harga dan biaya produksi, serta kemampuan untuk menerobos pasar, meningkatkan pangsa pasar, dan memberikan pelayanan yang profesional. 
Membangun sistem dan usaha yang berdaya saing dipengaruhi oleh dua faktor strategis yaitu (i) sisi permintaan, dan (ii) sisi penawaran. Dari sisi permintaan, terbuka peluang-peluang pasar yang cukup besar akibat globalisasi. Peluang-peluang yang muncul akibat keterbukaan pasar harus dapat diterjemahkan dalam pengembangan agribisnis yang dihela oleh pasar (market driving). Pasar berubah sangat cepat, menuntut produk-produk yang mengarah ke produk olahan dan bermutu, sehingga menghendaki pengembangan produk (product development) yang cepat pula. Perubahan pasar yang demikian cepat, baik di pasar ekspor maupun pasar domestik harus ekslporasi dengan baik agar produsen dapat menyesuaikan produk-produknya dengan selera pasar. Paradigma orientasi produksi yang ditempuh sejak dulu harus segera digeser ke orientasi pasar untuk memproduksi produk yang diinginkan oleh pasar (dari market what you can produce ke produce what you can market).

Dalam upaya menciptakan usaha-usaha agribisnis yang berdaya saing, harus dilakukan kebijaksanaan untuk menumbuhkan pengusaha-pengusaha mandiri yang tidak menggantungkan diri kepada pemerintah. Pemerintah perlu menciptakan iklim usaha yang kondusif, dan melakukan pelatihan manajemen untuk menumbuhkembangkan usaha-usaha agribisnis yang tangguh.

\section{Membangun Sistem dan Usaha Agribisnis Berkerakyatan}

Sistem yang berkerakyatan dicirikan oleh berkembangnya usaha produktif yang melibatkan masyarakat secara luas baik dalam peluang berusaha, kesempatan kerja, maupun dalam menikmati nilai tambah (pendapatan). Hal ini tidak berarti harus hanya memperhatikan usaha skala kecil dan menengah, tetapi juga usaha skala besar dalam konsep kerjasama (kemitraan yang Win-Win Innelition) dengan usaha kecil dan menengah, dan yang mempunyai dampak multiplier yang besar.

Dalam mewujudkan suatu sistem agribisnis yang berkerakyatan, peningkatan kemampuan sumberdaya manusia dan organisasi ekonomi seperti usaha rumah tangga, koperasi/kelompok, usaha kecil, usaha menengah beserta jaringan usahanya (network business) menjadi perhatian utama yang perlu dipromosikan pemerintah. Di masa lalu, para petani yang merupakan kelompok terbesar dari rakyat Indonesia, terbatas hanya mengusahai dan menguasai mata rantai yang memberikan nilai 
tambah terkecil yakni sub-sistem usahatani. Mata rantai agribisnis yang memberikan nilai tambah terbesar yakni sub-sistem agribisnis hulu dan hilir tidak pernah mengikutsertakan petani.

Dalam upaya membangun sistem agribisnis berkerakyatan, tetap diperlukan partisipasi usaha swasta asing (PMA). Partisipasi usaha swasta pada pembangunan sistem agribisnis ditempatkan dalam kerangka memperkuat organisasi ekonomi rakyat dan bukan menggantikan atau menyingkirkan organisasi ekonomi rakyat banyak. Oleh karena itu bentuk-bentuk joint operation atau joint venture antara UKM dan Koperasi dengan PMA pada sistem agribisnis perlu dikembangkan.

\section{Membangun Sistem dan Usaha Agribisnis Yang Berkelanjutan}

Berkelanjutan diartikan sebagai kemampuan untuk meningkatkan kapasitas sumberdaya agribisnis yang semakin besar dari waktu ke waktu, yang semakin mensejahterakan masyarakat, baik secara ekonomis, sosial, dan lingkungan hidup. Karena dalam sistem dan usaha agribisnis terdapat keterkaitan yang sangat kuat antara kepentingan para pelakunya termasuk antara lain konsumen, maka distribusi insentif ekonomi dan manfaat ekonomi di antara pelaku agribisnis merupakan faktor yang sangat penting dalam menjaga keberlanjutan sistem dan usaha agribisnis.

Membangun sistem dan usaha agribisnis yang berkelanjutan, memiliki dimensi yang luas baik secara organisasi, kelembagaan, ekonomi, teknologi dan ekologis. Organisasi dan kelembagaan baik dalam bidang ekonomi, maupun dalam pengelolaan pembangunan harus dikembangkan dengan melakukan hibridisasi organisasi dan kelembagaan tradisional-lokal dengan organisasi dan kelembagaan modern, sehingga akan terbangun suatu sistem yang berakar kokoh dalam budaya bangsa namun akomodatif terhadap perkembangan jaman.

Pengembangan teknologi dalam sistem agribisnis mulai dari hulu sampai ke hilir perlu diarahkan kepada teknologi yang ramah lingkungan (green industry) dalam kerangka mewujudkan suatu industri yang bersahabat dengan lingkungan. Dengan demikian keseluruhan kegiatan ekonomi yang dikembangkan akan menuju suatu perekonomian yang mengakomodir pelestarian lingkungan (green economy). 


\section{Membangun Sistem dan Usaha Agribisnis Yang Desentralistis}

Desentralistis diartikan bahwa kegiatan ekonomi ditentukan oleh masyarakat pelaku sesuai dengan kondisi wilayahnya atas dasar keunggulan komparatif dan aspirasi masyarakat setempat. Oleh karena itu sistem pelayanan pemerintah, sistem penunjang dan pemberdayaan masyarakat akan bersifat lokal, beragam dan harus dilakukan oleh daerah setempat. Dengan demikian, secara alamiah pembangunan sistem agribisnis pada hakekatnya merupakan pembangunan ekonomi daerah. Hal ini sesuai dengan esensi otonomi daerah yakni melakukan desentralisasi dan pemerataan pembangunan yang berkeadilan.

Dalam kerangka pemberdayaan organisasi ekonomi masyarakat luas sebagai pelaku utama sistem agribisnis, pembagian tugas dan tanggung jawab pemerintah pusat dan pemerintah daerah (propinsi dan kabupaten) perlu dilakukan. Pemerintah pusat akan difokuskan pada empat hal pokok yakni : (1) Memberdayakan DinasDinas daerah agar mampu mengelola pembangunan sistem dan usaha agribisnis di daerah masing-masing; (2) Meng-orkestra pembangunan sistem agribisnis antar daerah (propinsi) agar dapat berjalan secara sinergis dan harmonis; (3) Menangani aspek-aspek pembangunan sistem agribisnis yang menyangkut kepentingan beberapa daerah dan atau menangani aspek-aspek pembangunan sistem agribisnis yang tidak efisien dan efektif diserahkan pembangunannya pada satu daerah (propinsi) dan (4) Menangani dan mengkoordinasikan kebijaksanaan ekonomi sektoral, antar sektor, makro ekonomi dan perdagangan/kerjasama internasional.

Langkah-Langkah Untuk Menjaga Konsistensi Pembangunan Ekonomi Yang Berkelanjutan

\section{Pengembangan SDM}

Pengembangan sumberdaya manusia (SDM) merupakan hal penting yang perlu diperhatikan dalam pembangunan sistem dan usaha agribisnis. Hal ini disebabkan karena dalam pembangunan sistem dan usaha agribisnis, SDM tidak hanya sekedar faktor produksi melainkan yang lebih penting lagi adalah pelaku langsung dari pembangunan sistem dan usaha agribisnis.

Untuk membangun sistem agribisnis, paling sedikit terdapat tiga sasaran penting pengembangan SDM agribisnis di Indonesia. Pertama adalah 
mengembangkan kemampuan penguasaan teknologi dan pengetahuan sehingga searah dengan pengembangan teknologi pada sistem dan usaha agribisnis; Kedua, mengembangkan kemampuan kewirausahaan (enterpreneurship) sehingga dapat menjadi pelaku-pelaku ekonomi yang handal/tangguh dan Ketiga, mengembangkan kemampuan team work. Sumberdaya manusia agribisnis dalam hal ini mencakup SDM agribisnis pelaku langsung seperti tenaga kerja yang bekerja pada sub-sektor agribisnis hulu, sub-sektor on-farm agribusiness dan sub- sektor agribisnis hilir, dan SDM agribisnis pendukung sektor agribisnis seperti birokrat pusat hingga ke daerah, SDM perbankan dan SDM penyedia jasa bagi agribisnis.

Kualitas dan kemampuan aparat yang mampu meningkatkan kreativitas sumberdaya manusia pelaku agribisnis merupakan bagian yang tidak terpisahkan dengan pembangunan sistem dan usaha agribisnis. Perkembangan tahapan kemajuan sistem agribisnis sangat tergantung pada tingkat keahlian yang dimiliki oleh pelaku agribisnis. Oleh karena itu perlu dibuat berbagai kebijaksanaan yang dapat mengefektifkan fungsi penyuluhan dengan sasaran khusus pengembangan sistem dan usaha agribisnis. Sasaran penyuluhan perlu diperluas tidak hanya pada petani, tetapi juga pelaku agribisnis lainnya. Demikian pula lingkup penyuluhan harus mencakup agribisnis hulu, on-farm dan agribisnis hilir (termasuk pemasaran). Disamping itu penyuluhan dalam rangka pengembangan kelembagaan ekonomi petani juga perlu dilakukan. Khusus untuk penyuluhan dengan sasaran petani sebagai salah satu pelaku agribisnis, pendekatan penyuluhan partisipatif perlu dijadikan kebijaksanaan pengembangan penyuluhan.

\section{Pengembangan Organisasi Ekonomi Petani}

Pembangunan sistem dan usaha agribisnis yang dari rakyat, oleh rakyat dan untuk rakyat disetiap daerah memerlukan pengembangan kelembagaan dan organisasi ekonomi. Akibat paradigma pembangunan dimasa lalu banyak kelembagaan tradisional/lokal yang sebelumnya bagian dari perekonomian lokal menjadi rusak bahkan hilang. Oleh sebab itu, kelembagaan tradisional/lokal perlu dibangkitkan kembali dan didayagunakan untuk pembangunan sistem dan usaha agribisnis. 
Kelembagaan pangan tradisional seperti kelembagaan lumbung desa/keluarga disetiap daerah perlu dikembangkan kembali dan dijadikan sebagai kelembagaan ketahanan pangan (food security) nasional. Sistem kelembagaan pangan yang berbasis pada keanekaragaman bahan pangan dan budaya lokal akan mampu menjadi sistem ketahanan pangan nasional yang tangguh dan efisien. Oleh karena itu kelembagaan pangan yang demikian perlu dihidupkan kembali.

\section{Pengembangan Pusat-Pusat Pertumbuhan Agribisnis Daerah}

Keseluruhan kebijaksanaan pengembangan sistem dan usaha agribisnis seperti sudah dikemukakan terdahulu secara operasional akan terjadi di daerah karena disanalah basis sumberdayanya.

Untuk mengoperasionalisasikan pembangunan sistem dan usaha agribisnis, perlu dikembangkan atau diorganisasikan dalam bentuk pusat-pusat pertumbuhan agribisnis di daerah sesuai dengan keunggulan masing-masing daerah. Pengembangan pusat-pusat agribisnis tersebut harus dikaitkan dengan ekonomi regional sedemikian rupa sehingga secara bertahap agribisnis daerah yang bersangkutan makin terintegrasi dengan perekonomian regional dan dunia. Tentu saja disamping penumbuhan pusat-pusat agribisnis secara fisik, pengembangan sistem informasi agribisnis juga perlu dilakukan.

Pada pusat-pusat pertumbuhan agribisnis perlu diperlengkapi infrastruktur yang diperlukan seperti jalan baik yang menghubungkan industri pengolahan dengan sub-sistem on-farm maupun antar pusat pertumbuhan agribisnis dengan pelabuhan ekspor. Selain itu juga dikembangkan fasilitas pergudangan, terminal agribisnis, dan bursa komoditas/produk agribisnis, beserta fasilitas lain yang diperlukan untuk berkembangnya sistem dan usaha agribisnis.

\section{Kesimpulan}

Pembangunan ekenomi berbasis agribisnis merupakan strategi pembangunan ekonomi yang berbasis pada pendayagunaan kemampuan rakyat banyak ( membangun perekonomian yang memiliki local conten-nya tinggi ) dalam bidang agraris dimana pertumbuhan dan pemerataan ekonomi terwujud sekaligus. Pembangunan tersebut harus memerankan rakyat sebagai subjek ( pelaku ) ekonomi 
tersebut, sementara itu potensi yang belum digali merupakan peluang untuk memerankan rakyat sebagai pelaku dalam pembangunan tersebut. Keunggulan komperatif dan kompetitif merupakan modal utama untuk mengangkat sebuah wilayah sebagai master pembangunan saat ini.

Keunggulan sektor agrobisnis merupakan peluang emas. Adapun agribisnis yang dimaksudkan dalam hal ini mengacu pada pertanian agribisnis yang terdiri dari :Pertama, sub sektor agribisnis hulu yang meliputi pembibitan/pembenihan, agrootomotif (mesin dan peralatan pertanian), agro-kimia (pupuk, pestisida, obat /vaksin ternak). Kedua, sub sektor usaha tani / pertanian primer, mencakup usaha tanaman pangan, hortikultura, perkebunan, perikanan, peternakan dan kehutanan. Ketiga, sub-sektor agribisnis hilir, meliputi industri-industri pengolahan pertanian termasuk food service industri dan perdagangannya. Keempat, sub sektor jasa, seperti perkeriditan, asuransi, transportasi, penelitian dan pengembangan, pendidikan, penyuluhan-konsultasi, infrastruktur dan kebijakan pemerintah. Jadi sektor agribisnis mencakup pertanian dan industri serta jasa boga terkait dengannya.

Kebijakan pengembangan agribisnis sebagai mata rantai ekonomi harus mendapat dukungan yang jelas dari pemerintah., apalagi untuk saat ini diterapkannya otonomi daerah merupakan peluang yang tepat bagi pemerintah daerah untuk kembali menggali potensi daerahnya dengan pemanfaatan sektor agribisnis untuk membangun secaraberkesinambungan (sustainable development). Sementara itu, peran pemerintah dalam hal ini, bertindak selaku fasilitator yang menfasilitasi berbagai prakarsa masyarakat, dengan memberikan stimilasi dana, sesuai dengan kemampuan anggarannya.

Dengan pengembangan agribisnis seperti ini, dalam pertumbuhannya diharapkan akan mampu menghela aktivitas dinamika perekonomian yang berbasis pertanian didaerah periferal dan penyangga, yang kemudian pada gilirannya akan mengeliminasi perkembangan arus urbanisasi dari daerah-daerah tersebut dan yang paling penting adalah terciptanya pembangunan ekonomi yang berkesinambungan. 


\section{Daftar Pustaka}

http://sumbawa.tripod.com

FRONTIR Nomor 33, Maret 2001

Saragih, Bungaran, "Pengembangan Agribisnis Dalam Pembangunan Ekonomi Nasional Menghadapi Abad Ke-21"

Nasional"

"Pembangunan Sistem Agribisnis SebagaiPenggerak Ekonomi

http://www.bappenas.go.id/pnData/ContentExpress/RPJP/04\%20Draft\%20RPJP\%2 0(Final)\%204\%20Feb\%202005.doc.

Krisnamurti, Bayu. "Peran Pembangunan Pertanian dalamPembangunan Industri dan Daerah" Studi Kasus Cianjur dan Subang. 